\title{
The Influence of Board Independent on Firm Performance of Sri Lankan Listed Companies
}

\author{
M. C. A. Nazar \\ Senior Lecturer, Department of Accountancy and Finance, South Eastern University of Sri Lanka, \\ University Park, 32360, Oluvil, Sri Lanka \\ mcanazar@seu.ac.lk
}

\begin{abstract}
The study investigates the effect of board independent on firm performance of Sri Lankan listed companies. This study employs a cross section analysis of 120 firms as sample of listed firms in Colombo Stock Exchange (CSE) for the financial year ending2019 and multivariate analyses are used to test the proposed hypothesis. The board independent variable being the independent variable and firm performance (ROA) variable being the dependent variable a re confirmed under regression model. The results of the study display that board independence is negatively connected with ROA. Further, Board size and CEO duality are significantly negatively associated with ROA. Moreover, a control variable of firm size is significantly positively connected with ROA and leverage is negatively related with ROA though not significant. The findings of the study indicate mixed results which are in consistent with empirical evidence of developed nation.
\end{abstract}

Keywords - Board Independent; Board of Directors; Firm Performance; ROA.

\section{Introduction}

Corporate boards are the principal and leading inside corporate governance devices and play an important part in the monitoring management and bring into line the interest of shareholders with management (Brennan, 2006). Good corporate governance demonstrates itself in the efficiency of the directorate and the management of the company. The board of directors is accountable for mitigating self-interest activities as well as dropping losses caused by sub-optimal decisions by executives (Fama \& Jensen, 1983; Jensen \& Meckling, 1976). The board efficiency remains hard to understand and define, as there is major argument about the roles and tasks that would be allocated to the board. The board efficiency dimensions include searching the environment for threats and opportunities offer direction and feedback to the CEO; and, draw out a network of contacts and sources of knowledge to strengthen firm performance (Leung et al., 2014). This is a broader definition than the traditional board effectiveness in monitoring and controlling managers.

The recently revised code of best practice on corporate governance 2013 was issued by the Institute of Chartered Accountants of Sri Lanka and Securities and Exchange Commission. The code recommends that the board to have a balance of executive and Nonexecutive directors such that no individual or small group of individuals can control the board's decision making process. In addition, commends that the responsibility of both the chairman and the CEO should not hold by the same person to ensure the balance of power and authority. This paper is structured as follows. In Section 2, we reviewed the theoretical and empirical literature and hypothesis development. In Section 3, the data and methodology are presented. In Section 4, the results are discussed and Section 5 concluded.

\section{Literature Review and Hypothesis Development}

The board of directors might contain executive and non-executive memberships. The non-executive directors play a dynamic part in monitoring the movements of the CEO and executive directors to confirm that the interest of shareholders are healthy be concerned for and to add to the diversity of skills and knowledge of the directors (Weir \& Laing, 2001). Consistent with this argument, Liu et al. (2015) found a positive association between nonexecutives and firm performance measured by return on asset (ROA) and return on equity (ROE) in Pakistan.

Existing work in the analytical agency tradition (Stiles and Taylor, 2001) suggests that a higher proportion of outside directors should be associated with stronger financial performance. Furthermore, Zubaidah et al. (2009) found that independent non-executive directors contribute significantly in the long term performance of the company. In addition, Dehaenc et al. (2001) concluded that there was a significant positive relationship between the independent directors' percentage in a firm and return on equity (ROE) among Belgium companies. O' Connell and Creamer (2010) found that there was a positive and significant association between the percentage of non- executive directors on the board and firm performance. Furthermore, Dahya and McConnell (2005) found the same results in the UK firms. The appointment of financial outside directors to a public corporation is

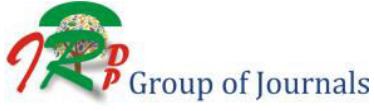


as sociated with pos itive abnormal return among medium size companies (Lee et al,1999). On the other hand, Agrawal and Knoeber (1996) found a significant negative relationship between outside board members and firm performance. This result is also supported by Bhagat and Black (1999) with the findings of firms having more outside directors performs poorer than other firms.

However, some other studies like those of Kajola (2008) and Peng (2004) found insignificant association between the ratio of outside directors to the whole board and its effect on firm performance. Empirically, research on non-executive director in relation to firm performance is inconsistent. Therefore, the hypothes is can be formulated as follows:

$\mathrm{H}_{1}$ : There is positive relationship between the percentage of independent non-executive director and firm performance (ROA).

\section{Data Analysis and Research Method}

\subsection{Data and Sample}

The data use in the form of secondary data. The data and information for this study collected from the Colombo Stock Exchange (CSE) websites, annual reports, journals and CSE publications. The total listed companies in the CSE contained 293 companies in 2019 have been categories under 20 different sectors. The sample consists of 120 non-financial public listed companies in Sri Lanka whose annual reports are available in 2019.

\subsection{Research Model}

A cross - sectional ordinary least square regression model used test the developed hypotheses for this study. The regression model utilized to test the relationship between the board independence and ROA are as follows:

Return on Assets (ROA) $=\alpha+\beta_{1}$ Board Independent + $\beta_{2}$ Board size $+\beta_{3}$ CEO Duality $+\beta_{4}$ Firm size $+\beta_{5}$ Leverage + ei

\subsection{Variables and Descriptions}

Return on Asset = Net Income / Total Assets

Board Independent $=$ No. of outside directors / Total No. of directors

Board Size $=$ No. of directors on the board

CEO Duality = It is equal to one if the post is hold by same person as the CEO and board Chair, or is zero otherwise

Firm size = Natural log of total assets reported on annual report

Leverage $=$ Total debt $/$ Total equity

\section{Data Analysis and Discussions}

Descriptive statistics is necessary to obtain sample characteristics. Table 1 provides descriptive statist ics for the variable of board characteristics used in the study.

\subsection{Descriptive Analysis}

Table 1: Descriptive $S$ tatistics

\begin{tabular}{|c|c|c|c|c|c|c|}
\hline & ROA & $\begin{array}{l}\text { Board } \\
\text { Independence }\end{array}$ & Board Size & CEO Duality & Firm Size & Leverage \\
\hline Mean & 0.062 & 0.715 & 7.940 & 0.138 & 9.665 & 0.367 \\
\hline Median & 0.057 & 0.714 & 8.000 & 0.000 & 9.694 & 0.140 \\
\hline Maximum & 0.544 & 1.000 & 12.000 & 1.000 & 11.202 & 7.371 \\
\hline Minimum & -0.793 & 0.250 & 3.000 & 0.000 & 8.056 & 0.000 \\
\hline Std. Dev. & 0.120 & 0.204 & 1.966 & 0.346 & 0.618 & 0.777 \\
\hline Skewness & -2.260 & -0.245 & 0.271 & 2.100 & -0.118 & 6.678 \\
\hline Kurtosis & 26.678 & 2.246 & 2.493 & 5.410 & 2.931 & 58.418 \\
\hline Jarque-Bera & 2808.536 & 3.906 & 2.657 & 113.333 & 0.292 & 15706.160 \\
\hline Probability & 0.000 & 0.142 & 0.265 & 0.000 & 0.864 & 0.000 \\
\hline Sum & 7.165 & 82.897 & 921.000 & 16.000 & 1121.136 & 42.593 \\
\hline Sum Sq. Dev. & 1.650 & 4.777 & 444.578 & 13.793 & 43.877 & 69.514 \\
\hline Observations & 120 & 120 & 120 & 120 & 120 & 120 \\
\hline
\end{tabular}


Descriptive statistics of the variables are presented in Table 1.The descriptive statistics include the mean, median, standard deviation, minimum and maximum values. The average firm performance (ROA) is $6.2 \%$. On average $71 \%$ of overall board members are independent directors, a range of $25 \%$ to $100 \%$ of total directors. The number of directors on Sri Lankan board is between 3 and 12 with an average board size in the selected firms is about

8 persons. This result is reliable with the study by Fooladi (2012) and Zubaidah et al (2009). In addition, of all the firms studied, $87 \%$ of the m adapt the 2 tier board structure implying that about $13 \%$ of the firms have their CEOs and Board chairman positions combined in one personality. This suggests that way for agency problems originating from conflict of interest are minimized.

\subsection{Correlation Analysis}

Table2: Correlation results

\begin{tabular}{|l|l|l|l|l|l|l|}
\hline & ROA & $\begin{array}{c}\text { Board } \\
\text { Independence }\end{array}$ & Board Size & $\begin{array}{c}\text { CEO } \\
\text { Duality }\end{array}$ & Firm Size & Leverage \\
\hline ROA & 1 & & & & & \\
\hline Board Independence & -0.141 & 1 & & & & \\
\hline Board Size & -0.116 & $-0.177^{* *}$ & 1 & & & \\
\hline CEO Duality & $-0.168^{*}$ & -0.105 & -0.039 & 1 & & \\
\hline Firm Size & $0.229^{* * *}$ & $-0.277^{* * *}$ & $0.307^{* * *}$ & -0.009 & 1 & \\
\hline Leverage & -0.102 & 0.084 & 0.040 & -0.024 & $0.184^{* *}$ & 1 \\
\hline
\end{tabular}

* Correlation is significant at the 0.1 level (2-tailed)** Correlation is significant at the 0.05 level (2-tailed) *** Correlation is significant at the 0.01 level (2-tailed)

Table 2 shows the correlation results among the variables. Board independence is negatively correlated with ROA. And also, board size is negatively correlated with ROA. In addition, CEO duality is significantly negatively correlated with ROA at the
$10 \%$ level. Furthermore, Firm size is significantly positively correlated with ROA. But, leverage is negatively linked with ROA.

\subsection{Regression Analysis}

Table 3: Regression results

\begin{tabular}{|l|r|r|r|r|}
\hline \multicolumn{5}{|c|}{ Dependent Variable: ROA } \\
\hline \multicolumn{5}{|c|}{ Included observations: 120 } \\
\hline \multicolumn{7}{|c|}{ Coefficient } & \multicolumn{1}{c|}{ Std. Error } & t-S tatistic & Prob. \\
\hline & & & & 0.1386 \\
\hline C & -0.252609 & 0.169308 & -1.492013 & 0.3485 \\
\hline BIND & -0.045822 & 0.048667 & -0.941527 & 0.0388 \\
\hline BOARDSIZ & -0.010536 & 0.005038 & -2.091384 & 0.0326 \\
\hline CEODUAL & -0.058673 & 0.027098 & -2.165181 & 0.0095 \\
\hline FIRMSIZE & 0.044606 & 0.016883 & 2.642047 & 0.1785 \\
\hline LEVERAGE & -0.016773 & 0.012387 & -1.354105 & \\
\hline & & & & \\
\hline R-squared & 0.348373 & & & \\
\hline Adjusted R-squared & 0.306138 & & & \\
\hline
\end{tabular}

Table 3 shows the regression between board characteristics and ROA. The relationship between the number of the independent directors from the board and firm performance (ROA) is not statistically significant; the board composition has a negative relationship with ROA though insignificant. This is consistent with the findings of Agrawal and Knoeber (1996) and Bhagat and black (1999). and Nelson (1999). In accordance with the available
Therefore, Hypothesis 1 which stated that there is positive relationship between the percentage of independent non-executive director and firm performance is rejected and null hypotheses accepted. Further, the size of the board of directors and CEO duality are significantly negatively associated with ROA. These findings are supported with Yermack (1996) and Fosberg literature, the study includes control variables in the 
regression analysis. Table 3 indicates that firm size is significantly positively interrelated with ROA. Leverage is negatively influence on firm performance (ROA).

\section{Conclusion and Limitations}

This study explores whether the board independent influence on firm performance (ROA) for 120 firms as sample of listed companies in Colombo Stock Exchange. This research used the ROA as proxy measurer for firm performance. The results of the study provide that board independent does not influence significantly and positively on ROA. In contrast it is negatively affect the ROA. Although it is widely believed that, outside directors will promote shareholders wealth due to their legally vested responsibility and although board independent is recommended in many international corporate codes of best practices, even in Sri Lanka. The reason may be behind this result, it is contended that insider directors are the most effective directors because they have more information about the firm than outsider directors and thus outside directors must rely on them to make decisions. Further both board size and CEO duality are significantly negatively associated with ROA. In the case of control variables, firm size is significantly positively related with ROA and leverage is negatively associated with ROA. The results of the study are mostly consistent with the previous studies and it shows the importance of board characteristics should be highlighted in order to improve the firm performance.

The major limitations of this study are as follows: First, the study based on the cross sectional study which is concern about one year period may not provide more generalized result. Second, this study used only ROA as a performance measure can include ROE, ROCE and Tobin $\mathrm{Q}$ in order to get generalized results. It is highly recommended that future research should be analyzed more than one year because the effect of independent.

\section{References}

[1] Agrawal, A., \& Knoeber, C. R. (1996).Firm performance and mechanisms to control agency problems between managers and shareholders .Joumal of Financial and Quantitative Analysis, 31(3), 377-397.

[2] Akbar, M.,Hussain, S., Ahmad, T., \& Hassan, S. (2019) Corporate governance and firm performance in Pakistan: Dynamic Panel Estimation. Abasyn Journal of Social Sciences, 12 (2).213-230.

[3] Bhagat, S., \& Black, B. (1999). The uncertain relationship between board composition and firm performance. The Business Lawyer, 921-963.

[4] Brennan, N. (2006). Boards of directors and firm performance: is there an expectations gap? Corporate Govemance: An International Review, 14(6), 577-593.

[5] Dahya, J., \&Mc Connell, J.J. (2005), Outside directors and board decision, Journal of corporate Finance, 11(1-2), 37-60.

[6] Dehaene, A., De Vuyst, V., \&Ooghe, H. (2001). Corporate performance and board structure in Belgian companies. Long Range Planning, 34(3), 383-398.

[7] Fama, E. F., \& Jensen, M. C. (1983).Separation of ownership and control. The Journal of Law \& Economics, 26(2), 301-325.

[8] Fooladi, M. (2012).Board characteristics and firm performance, Journal of Modern Accounting and Auditing, 8(5), 688-694.

[9] Fosberg, R.H., \& Nelson, M.R., (1999), Leadership structure and firm performance, International Review of Financial Analysis, 8(1), 83-96.

[10] Jensen, M.C., \& Meckling, W.H.(1976),Theory of the firm: managerial behavior, agency cost and ownership structure, Journal of Financial Economics, 3, 305-360.

[11] Lee, Y.S., Rosenteins, S., \& Wyatt, J.G. (1999).The value of financial out side directors on corporate boards, International Review of Economics and Finance, 8(4), 421-431.

[12] Leung, S., Richardson, G., \& Jaggi, B. (2014). Corporate board and board committee independence, firms performance, and family ownership concentration: An analysis based on Hong Kong firms, 10(1), 16-31.

[13] Liu, Y., Miletkov, M. K., Wei, Z., \& Yang, T. (2015).Board independence and firm performance in China.Journal of corporate Finance, 30, 223-244.

[14] O'Connell, V., \& Cramer, N. (2010).The relationship between firm performance and board characteristics in Ireland. European Management Journal, 28(5), 387-399.

[15] Stiles, P. \& Taylor, B. (2001) Boards at work: how directors view their roles and responsibilities. Oxford University Press, Oxford.

[16] Weir, L. \& Laing.D. (2001). Governance structures, director independence and corporate performance in the U.K. European Business Review, 13(2), 86-94, 2001.

[17] Yermack, D. (1996). Higher market valuation of companies with a small board of directors. Journal of Financial Economics, 40(2), 185-211.

[18] Zubaidah, Z.A., Nurmala, M.K., \& Kamaruzaman, J. (2009), Board structure and corporate performance in Malaysia, International Journal of Economics and Finance, Vol. 1(1), pp. 150-164.

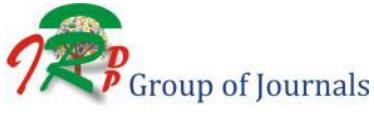

